FROM OLD ENGLISH

TO STANDARD ENGLISH 


\section{Studies in English Language series}

A Course Book in English Grammar, 2nd Edition -

Dennis Freeborn

From Old English to Standard English, 2nd Edition -

Dennis Freeborn

Style: Text Analysis and Linguistic Criticism - Dennis Freeborn Varieties of English, 2nd Edition - Dennis Freeborn with

Peter French and David Langford

Analysing Talk - David Langford

English Language Project Work - Christine McDonald 


\title{
FROM OLD ENGLISH TO STANDARD ENGLISH
}

\section{A COURSE BOOK IN LANGUAGE VARIATION ACROSS TIME}

\author{
Second Edition
}

\author{
Dennis Freeborn
}


(C) Dennis Freeborn 1992, 1998

Softcover reprint of the hardcover 1st edition 1998 978-0-333-69154-0

All rights reserved. No reproduction, copy or transmission of this publication may be made without written permission.

No paragraph of this publication may be reproduced, copied or transmitted save with written permission or in accordance with the provisions of the Copyright, Designs and Patents Act 1988, or under the terms of any licence permitting limited copying issued by the Copyright Licensing Agency, 90 Tottenham Court Road, London W1P 9HE.

Any person who does any unauthorised act in relation to this publication may be liable to criminal prosecution and civil claims for damages.

The author has asserted his rights to be identified as the author of this work in accordance with the Copyright, Designs and Patents Act 1988.

\section{Published by}

\section{MACMILLAN PRESS LTD}

Houndmills, Basingstoke, Hampshire RG21 6XS

and London

Companies and representatives

throughout the world

ISBN 978-0-333-69155-7 ISBN 978-1-349-26665-4 (eBook)

DOI 10.1007/978-1-349-26665-4

A catalogue record for this book is available from the British Library
$\begin{array}{lllllll}10 & 9 & 8 & 7 & 6 & 5 & 4\end{array}$
$\begin{array}{llllllll}07 & 06 & 05 & 04 & 03 & 02 & 01 & 00\end{array}$

Typeset in Great Britain by

Aarontype Limited

Easton, Bristol 


\section{Contents}

Preface to the second edition

\section{INTRODUCTION}

I.I English today

1.2 Studying variety across time in language

1.3 How has the English language changed?

1.4 How can we learn about Old English and later changes in the language?

I.5 Changes of meaning - the semantic level

2 THE ENGLISH LANGUAGE IS BROUGHT TO BRITAIN 9

2.1 Roman Britain 9

2.2 The Anglo-Saxon Chronicle 9

2.3 How the English language came to Britain 12

3 OLD ENGLISH (I) 2I

3.1 Written Old English 2I

3.2 Dialects and political boundaries 35

3.3 Danish and Norwegian Vikings 37

3.4 Effects of Viking settlement on the English language 46

3.5 The Norman Conquest 51

4 OLD ENGLISH (II) 55

4.I The language of Old English poetry 55

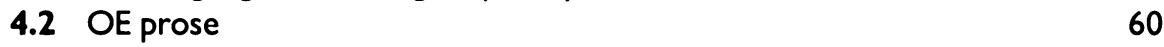

4.3 OE grammar 65 
4.4 Latin loan-words in OE 71

4.5 ON loan-words in OE

4.6 Early French loan-words 74

5 FROM OLD ENGLISH TO MIDDLE ENGLISH 76

$\begin{array}{ll}\text { 5.I The evidence for linguistic change } & 76\end{array}$

5.2 The Norman Conquest and the English language 77

5.3 The earliest 12th-century Middle English text 82

5.4 The book called Ormulum $\quad 86$

5.5 12th-century loan-words 96

6 EARLY MIDDLE ENGLISH - 12th CENTURY 98

6.I Evidence of language change from late $O E$ to early $M E$ in Lazamon's Brut $\quad 98$

6.2 The Owl \& the Nightingale 123

7 EARLY MIDDLE ENGLISH - I3th CENTURY 126

$\begin{array}{ll}\text { 7.I The Fox and the Wolf } & 126\end{array}$

$\begin{array}{ll}\text { 7.2 The South English Legendary } & 127\end{array}$

$\begin{array}{ll}7.3 & \text { A guide for anchoresses } \\ & 132\end{array}$

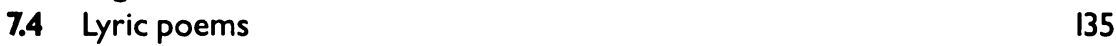

$\begin{array}{ll}\text { 7.5 The Bestiary } & 137\end{array}$

7.6 The Lay of Havelok the Dane 143

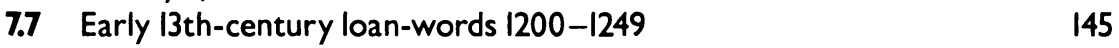

8 NORTHERN AND SOUTHERN TEXTS COMPARED 149

$\begin{array}{ll}\text { 8.I Cursor Mundi - a history of the world } & 149\end{array}$

8.2 Later 13th-century loan-words 1250-1299 161

9 THE 14th CENTURY - SOUTHERN AND KENTISH DIALECTS

9.I The dialect areas of Middle English 163

$\begin{array}{ll}\text { 9.2 How to describe dialect differences } & 169\end{array}$

$\begin{array}{ll}\text { 9.3 A South Eastern or Kentish dialect } & 170\end{array}$

\begin{tabular}{ll}
9.4 & An early South West dialect \\
\hline
\end{tabular}

9.5 A later 14th-century South West dialect $\quad 179$

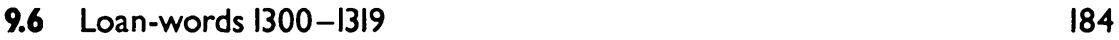

10 THE 14th CENTURY - NORTHERN DIALECTS 187

10.1 A 14th-century Scots English dialect 187

10.2 Another Northern dialect - York 191

10.3 The York Plays 195

10.4 Northern and Midland dialects compared 202

10.5 Chaucer and the Northern dialect 203

10.6 Loan-words 1320-1339 205 
II THE I4th CENTURY - WEST MIDLANDS DIALECTS

II.I A North-West Midlands dialect - Sir Gawayn and pe Grene Knzt 207

II.2 A South-West Midlands dialect - Piers Plowman 215

II.3 Loan-words 1340-1359

12 THE 14th CENTURY - EAST MIDLANDS AND LONDON DIALECTS

12.I The origins of present-day Standard English 224

12.2 A South-East Midlands dialect - Mandeville's Travels 225

12.3 The London dialect - Thomas Usk 227

12.4 Loan-words 1360-1379 229

13 THE LONDON DIALECT - CHAUCER,

LATE 14th CENTURY

13.I Chaucer's prose writing 231

$\begin{array}{ll}\text { 13.2 Chaucer's verse } & 236\end{array}$

$\begin{array}{ll}\text { I3.3 Editing a text } & 239\end{array}$

13.4 Loan-words 1380-1399 243

14 EARLY MODERN ENGLISH I - THE I5th CENTURY 247

14.I The beginnings of a standard language 247

14.2 Early 15th-century East Midlands dialect - The Boke of Margery Kempe 251

14.3 Later I5th-century East Midlands dialect - the Paston letters 255

14.4 Late 15th-century London English - William Caxton 257

14.5 The medieval tales of King Arthur 263

14.6 Late 15th-century London dialect - the Cely letters 266

14.7 15th-century loan-words 271

15 EARLY MODERN ENGLISH II - THE 16th CENTURY (i) 273

15.I The Lisle Letters 273

15.2 Formal prose in the 1530s 280

15.3 A different view on new words 287

15.4 John Hart's An Orthographie 289

15.5 The Great Vowel Shift 293

15.6 Punctuation in 16th-century texts 302

15.7 Loan-words 1500-1549 302

16 EARLY MODERN ENGLISH III - THE 16th CENTURY (ii) 305

16.I The development of the standard language 305

16.2 Evidence for some 16th-century varieties of English 308

16.3 English at the end of the 16th century 316

16.4 Loan-words 1550-1599 319 
17 EARLY MODERN ENGLISH IV - THE I7th CENTURY (i)

17.I Evidence for changes in pronunciation 322

17.2 Sir Thomas Browne 326

I7.3 George Fox's Journal 331

$\begin{array}{ll}17.4 \text { John Milton } & 337\end{array}$

$\begin{array}{ll}\text { I7.5 John Evelyn's Diary } & 340\end{array}$

I7.6 The Royal Society and prose style 342

I7.7 Loan-words 1600-1649 346

I8 EARLY MODERN ENGLISH V - THE 17th CENTURY (ii) 352

18.1 John Bunyan 352

18.2 Spelling and pronunciation at the end of the 17th century 355

18.3 John Dryden 366

18.4 North Riding Yorkshire dialect in the 1680s 371

18.5 Loan-words 1650-1699 372

19 MODERN ENGLISH - THE 18th CENTURY 376

19.1 Correcting, improving and ascertaining the language 376

19.2 Dr Johnson's Dictionary of the English Language 381

19.3 The perfection of the language 383

19.4 'The Genius of the Language' 384

19.5 Bishop Lowth's Grammar 386

19.6 'The depraved language of the common People' 388

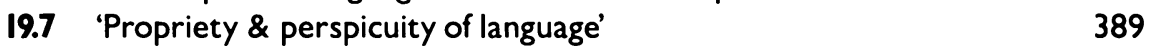

19.8 Language and social class 395

19.9 William Cobbett and the politics of language 398

19.10 18th-century loan-words 403

20 FROM OLD ENGLISH TO MODERN ENGLISH COMPARING HISTORICAL TEXTS 407

20.1 Commentary on Text $173 \quad 407$

20.2 'Your accent gives you away!' 410

2I POSTSCRIPT I - TO THE PRESENT DAY 418

21.I Some developments in the standard language since the 18th century 418

21.2 The continuity of prescriptive judgements on language use 420

21.3 The grammar of spoken English today 422

21.4 19th- and 20th-century loan-words 424

22 POSTSCRIPT II - ENGLISH SPELLING TODAY:

\section{A SUMMARY}

22.I The Roman alphabet and English spelling 431

22.2 The contrastive sounds of English 431

22.3 The spelling of vowels in English 433

22.4 The spelling of consonants in English 439 


\section{POSTSCRIPT III - THE DEVELOPMENT OF PRESENT-DAY} ENGLISH SPELLING: A SUMMARY

23.I Old English

23.2 After 1066 - Middle English

445

23.3 Early Modern English

450

23.4 Correct spelling today

Bibliography

458

Index

460 


\section{Preface to the second edition}

The text of the first edition has been completely revised and enlarged to include nearly two hundred historical texts, of which more than half are reproduced in facsimile. The facsimiles are primary sources of our knowledge of the language, illustrating the development of handwriting, printing, punctuation and spelling in a way which is not possible using modern printed versions of old texts.

The practice of modernising the spelling of modern printed texts of earlier English like, for example, the 15th-century Paston Letters and Shakespeare's late 16th- and early 17th-century plays has obscured important and interesting changes that have taken place. Literary texts are generally printed with modern spelling and punctuation, and though editions of Old and Middle English retain much of the original spelling, they usually add present-day punctuation.

\section{The texts}

The core of the book is the series of texts exemplifying the changes in the language from Old English to the establishment of Standard English. The texts have been selected for a number of reasons. The Old English texts are almost all from the Anglo-Saxon Chronicle, and so provide something of the historical context of the language a thousand years ago. Some texts have aspects of language itself as their subject. As we have no authentic records of the spoken language before the invention of sound recording, letters and diaries of the past are included, because they are likely to provide some evidence of informal uses of English. Some literary texts have been chosen, but the series does not constitute a history of English literature.

\section{Readership}

The first edition was intended for students of English Language at Advanced Level, but since publication in 1992 the book has been used in university departments of English, both in Britain and in over thirty overseas countries. As a 
result, the enlarged text aims to provide more material and commentary which is suitable for study in higher education. For example, Chapter 6 demonstrates how a relatively short extract from an early Middle English text can be analysed to demonstrate the evidence for changes from Old English in spelling, pronunciation, vocabulary and grammar that had occurred.

\section{Activities}

The Activities are designed to encourage students to find out for themselves - to answer the question 'how do you know?' and to consider possible reasons for what they observe. They are able to study data at first hand and to consider hypotheses, rather than to accept the answers to problems of interpretation that others have given. The process of analysing the texts in itself demonstrates how our knowledge of earlier English has been arrived at. The surviving corpus of Old and Middle English texts is all the evidence we have about the language as it was. There are no grammar books, descriptions of pronunciation, spelling books or dictionaries of English before the 16th century. The tasks in the Activities are no more than suggestions, and teachers will omit, modify and add to them as they think useful.

Many of the simpler, basic activities in the first edition have, however, been omitted, and teachers will readily devise them if they are needed.

\section{Levels of study}

It is helpful to consider three levels of study which may be followed according to students' needs, or to the amount of time available for study.

- At the first, observational level, features of the language can be simply noted and listed as interesting or different.

- At the second, descriptive level, such features are identified more specifically, using appropriate descriptive terms from a model of language.

- At the third, explanatory level, they are placed in their relation to general processes of language change, and in their social, political and historical context.

\section{Language change}

The English language, like all living languages, is in a continuous state of variation across time. The language of one generation of speakers will differ slightly from another, and at any one time there are 'advanced' and 'conservative' forms, whether they belong to regional, educational or class dialects. Change takes place at every level of language:

- Lexical level - new words are needed in the vocabulary to refer to new things or concepts, while other words are dropped when they no longer have any use in society. 
- Semantic level - the meaning of words changes - buxom once meant obedient, spill meant kill, and knight meant boy.

- Syntactic level - a word-for-word translation of some Old English is unlikely to read like grammatical contemporary English, because word order and grammatical structure have changed as well as vocabulary.

- Phonological level - pronunciation in particular is always being modified and varies widely from one regional or social group to another.

The process of change has, however, considerably slowed since the 18th century, because the spelling system and grammatical structure have been standardised and are therefore highly resistant to further change.

\section{Standard English}

Standard English has a unique and special status. Its prestige is such that for many people it is synonymous with 'the English language'. This book sets out to show what the origins of present-day Standard English were in the past. It is concerned principally with the forms of the language itself, and makes reference to the historical, social and political background to the establishment of Standard English in outline only.

\section{Commentaries}

Analytic commentaries are provided for some of the texts in the book. Each commentary is a case-study based upon the text itself, which provides some of the evidence for change in the language. Other texts are provided without commentary.

\section{Supplementary Materials}

Two supplementary books in typescript (photocopiable) and a cassette tape are available from the author for teachers, lecturers and advanced students.

\section{- Text Commentary Book}

The Text Commentary Book contains additional descriptive textual analyses which are indicated in From Old English to Standard English after the relevant texts and the sign . There is also one further chapter:

Chaucer's rhymes as evidence of changes in pronunciation.

\section{- Word Book}

The Word Book contains a complete word-list in alphabetical order for each Old and Middle English text. The lists for the Old English texts give the base form of inflected words and a translation, so that students can refer to an Old English dictionary or grammar more easily. Those for the Middle English texts include the derivation of each word. The Word Book also contains selected 
lists of words in present-day English which are derived from Old English, Old French, Old Norse or Celtic. These supplement the lists of loan-words which are included at the end of many of the chapters.

\section{- Cassette tape}

The cassette tape contains readings of the following texts:

\begin{tabular}{|c|c|c|c|}
\hline 1 & Texts $4 \& 5 b$ & Peterborough Chronicle & Old $\mathrm{F}$ \\
\hline 2 & Text 14 & Cadmon's hymn & $\begin{array}{l}\text { West } \\
\text { Old }\end{array}$ \\
\hline 3 & Text 33 & Peterborough Chronicle, 1140 & Early \\
\hline 4 & Text 35 & Ormulum, late 12 th $\mathrm{C}$ & $\begin{array}{l}\text { Early } \\
\text { En }\end{array}$ \\
\hline 5 & Text 53 & Ayenbyte of Inwit, 1340 & Kenti \\
\hline 6 & Text 59 & Barbour's Bruce, c. 1375 & Scot \\
\hline 7 & Text 62 & York Pentecost Play, c. 1470 & Nort \\
\hline 8 & Text 66 & Sir Gawayn and pe Grene Knyzt & Wes \\
\hline 9 & Text 68 & Piers Plowman, c. 1370 & West \\
\hline 10 & Text 82 & Friar's Tale, late 14th C & $\begin{array}{l}\text { East } 1 \\
\text { Eng }\end{array}$ \\
\hline 11 & Text 85 & Boke of Margery Kempe, c. 1420 & $\begin{array}{r}\text { East } \\
\text { En }\end{array}$ \\
\hline 12 & Text 89 & Paston Letters, c. 1480 & East \\
\hline 13 & Text 109 & $\begin{array}{l}\text { John Hart's An Orthographie, } \\
1569\end{array}$ & $\begin{array}{r}\text { Lond } \\
\text { En }\end{array}$ \\
\hline 14 & Text 120 & $\begin{array}{l}\text { Sir Thomas Browne's Of the } \\
\text { Badger, } 1646\end{array}$ & Early \\
\hline 15 & Text 146 & $\begin{array}{l}\text { Rhymes in John Dryden's Aeneis, } \\
\quad 1697\end{array}$ & Early \\
\hline \multicolumn{4}{|c|}{ Versions of 'Peter's denial' - St Matthew's Gospel, 26: 69-75 } \\
\hline 16 & Text 174 & Late West Saxon Old English & \\
\hline 17 & Text 175 & 14th C South Midlands Middle En & glish \\
\hline 18 & Text 176 & Early 16th C Scots Middle English & \\
\hline 19 & Text 177 & Early Modern English late 16 th $\mathrm{C}$ & \\
\hline 20 & Text 178 & Early Modern English early 17 th C & \\
\hline 21 & Text 179 & 20th C Scots & \\
\hline 22 & Text 180 & 20th C Modern English & \\
\hline 23 & Text 181 & 20th C Bislama (Vanuatu Pidgin E & nglish \\
\hline
\end{tabular}

A phonetic transcription follows each recorded text in this book.

For details of the supplementary books and cassette tape contact the author:

- by post: PO Box 82, Easingwold, York YO6 3YY

- by e-mail: freeborn (a nationwideisp.net

or visit his website

- http://homepages.nationwideisp.net/ freeborn 


\section{Acknowledgements}

The author and publishers wish to thank the following for permission to use copyright material:

Guardian News Services Ltd, for the extract from The Guardian, 24 August 1989; Newspaper Publishing plc, for the letters to The Independent by Daniel Massey, 14 November 1987, and Carol Clark, 25 November 1987.

Every effort has been made to trace all the copyright holders, but if any have been inadvertently overlooked the publishers will be pleased to make the necessary arrangement at the first opportunity. 


\section{Symbols}

$\begin{array}{ll}\text { Languages } & \\ \text { OE } & \text { Old English } \\ \text { ME } & \text { Middle English } \\ \text { EMnE } & \text { Early Modern English } \\ \text { MnE } & \text { Modern English } \\ \text { Fr } & \text { French } \\ \text { OF } & \text { Old French } \\ \text { ONF } & \text { Old Northern French } \\ \text { AN } & \text { Anglo-Norman } \\ \text { AF } & \text { Anglo-French } \\ \text { ON } & \text { Old Norse } \\ \text { MS } & \text { manuscript } \\ \text { fr } & \text { from }\end{array}$
$\mathrm{S} \quad$ subject (in clause structure)
$\mathrm{P} \quad$ predicator
C complement
O object
A adverbial
$\varnothing \quad$ stands for a deleted element in grammatical analysis

Writing and printing

Symbols used for OE letters in transcriptions of facsimiles:

\section{Grammar}

$\begin{array}{ll}\mathrm{m} & \text { masculine (gender) } \\ \mathrm{f} & \text { feminine } \\ \mathrm{n} & \text { neuter } \\ \text { nom } & \text { nominative (case) } \\ \text { acc } & \text { accusative } \\ \text { gen } & \text { genitive } \\ \text { dat } & \text { dative } \\ \text { sg } & \text { singular (number) } \\ \text { pl } & \text { plural }\end{array}$

ז

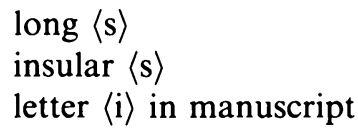

$\mathbf{p} / \mathbf{p} \quad$ letter thorn (lower case and capital)

ð/Ð letter eth (lower case and capital)

3/3 letter yogh (lower case and capital)

p/P letter wynn (lower case and capital)

$\not{p}$ abbreviation for pat

Letters in caret brackets identify written letters of the alphabet, e.g. $\langle e\rangle$.

Letters in square brackets identify spoken sounds, using the symbols of the International Phonetic Alphabet (IPA), e.g. [ə], [J], [ii]. The IPA symbols can be found in Gimson's Pronunciation of English, 5th edn, revised by Alan Cruttenden (London: Edward Arnold, 1994), p. 32, and Varieties of English, 2nd edn, Dennis Freeborn, with Peter French and David Langford (Basingstoke: Macmillan, 1993), Chapter 4, pp. 67-8. 


\section{Texts and facsimiles}

\section{Chapter 1}

1 Late West Saxon Old English $c .1050$

2 Late 14th-century Middle English, South Midlands 3

3 Early Modern English 1582

\section{Chapter 2}

4 The opening of the Peterborough Chronicle (facsimile) 10

5a Parker Chronicle for AD $47 \quad$ (facsimile) 11

5b Peterborough Chronicle for AD $47 \quad 11$

6a Peterborough Chronicle for AD 443 (facsimile) 13

6b Parker Chronicle for AD 443 (facsimile) 14

7 Peterborough Chronicle for AD 449 (facsimile) 15

8 Peterborough Chronicle for AD 455 (facsimile) 16

$\begin{array}{llll}9 a & \text { Peterborough Chronicle for AD } 519 \quad \text { (facsimile) } & 17\end{array}$

9b Parker Chronicle for AD $519 \quad$ (facsimile) 18

10a Peterborough Chronicle for AD 611 (facsimile) 19

10b Parker Chronicle for AD 611 (facsimile) 19

11a Peterborough Chronicle for AD 614 (facsimile) 19

11b Parker Chronicle AD 614 (facsimile) 19

\section{Chapter 3}

12a Peterborough Chronicle for AD 595 (facsimile) 30

12b Parker Chronicle version (facsimile) 30

13a Peterborough Chronicle for AD $601 \quad$ (facsimile) 31

13b Parker Chronicle version (facsimile) 31

14 Cadmon's hymn 32

15 From Testimonie of Antiquitie, A (1567) (facsimile) 34

16a Peterborough Chronicle for AD 628 (facsimile) 36

16b Parker Chronicle for AD 628 (facsimile) 36

17a Peterborough Chronicle for AD $787 \quad$ (facsimile) 37

17b Parker Chronicle for AD 787 (facsimile) 38 
18a Peterborough Chronicle for AD 793 (facsimile) 39

18b Parker Chronicle for AD $793 \quad 39$

19a Peterborough Chronicle for AD 878 (facsimile) 40

19b Parker Chronicle version 42

20 First lines of King $Æ$ Elfred's Preface to the West Saxon version of Gregory's Pastoral Care (facsimile)

21 From King Ælfred's Preface to the West Saxon version of Gregory's Pastoral Care (facsimile)

22 Inscription, St Gregory's Minster, Kirkdale, North Yorkshire ( facsimile)

23 Peterborough Chronicle for AD 937 (facsimile) 50

24 Part of the Parker Chronicle for 1066 (facsimile) 51

25 Part of the Peterborough Chronicle for $1066 \quad$ (facsimile) 52

\section{Chapter 4}

26 From the Parker Chronicle for AD 937 (facsimile) 55

27 A page from the manuscript of Beowulf (facsimile) 58

28 OE Gospels (Matthew 28: 8-19) (facsimile) 61

29 Wulfstan's Canons of Edgar (facsimile) 63

\section{Chapter 5}

30 Old English homily, copied second half of 12th century

$$
\text { (facsimile) }
$$

31 Anonymous short metrical chronicle, 14th century 80

32 Robert of Gloucester's Chronicle, c. $1300 \quad 81$

33 Part of Peterborough Chronicle for $1140 \quad 83$

34 Peterborough Chronicle for 1137, written c.1154 (facsimile) 84

35 Ormulum (i) $\quad 87$

36 Ormulum (ii) (facsimile) 88

\section{Chapter 6}

37 The opening of Lazamon's Brut (facsimile) 100

38 The Owl \& the Nightingale (facsimile) 124

\section{Chapter 7}

39 The Fox and the Wolf, early 13th century 126

40 Introduction to the Life of St Kenelm (facsimile) 128

41 The Southern Passion (facsimile) 130

42 Ancrene Wisse (facsimile) 133

43 Blow northerne wynd (facsimile) 135

44 Wip longyng y am lad (facsimile) 136

45 Lenten ys come wip loue to toune (facsimile) 137

46 The Bestiary - The Lion (facsimile) 137

47 The Bestiary - The Eagle 140

48 The Bestiary - The Whale 141

49 Havelok the Dane (facsimile) 143 


\section{Chapter 8}

50 Cursor Mundi, Northern and Southern texts (i)

150

51 Cursor Mundi (ii)

\section{Chapter 9}

52 Kentish dialect - Michael of Northgate's Ayenbyte of Inwyt,

$$
1340 \text { (i) (facsimile) }
$$

53 Kentish dialect - Michael of Northgate's Ayenbyte of Inwyt, 1340 (ii)

54 Kentish dialect - Michael of Northgate's Ayenbyte of Inwyt, 1340 (iii)

55 Robert of Gloucester's Chronicle (i) (facsimile)

56 Robert of Gloucester's Chronicle (ii)

57 John of Trevisa on the English language in 1385 (i)

58 John of Trevisa on the English language (ii)

\section{Chapter 10}

59 John Barbour on freedom, from The Bruce (i) 187

60 John Barbour's The Bruce (ii)

61 The York Proclamation for the Corpus Christi Plays, 1415

62 From the York Potters' Pentecost Play, c. $1470 \quad$ (facsimile)

63 The York Lay Folks' Catechism, 1357

\section{Chapter 11}

66 From Sir Gawayn and pe Grene Knyzt (i) (facsimile) 208

67 Sir Gawayn and pe Grene Knyzt (ii) 215

68 Piers Plowman (i) $\quad 216$

69 Piers Plowman (ii) (facsimile) 219

70 Piers Plowman (iii) (facsimile) 221

71 Piers Plowman (iv) (facsimile) 222

72 Piers Plowman (v) - edited version of Texts 70 and $71 \quad 222$

\section{Chapter 12}

73 The Travels of Sir John Mandeville (i) 226

74 The Boke of Mawndevile 226

75 The Travels of Sir John Mandeville (ii) (facsimile) 227

76 From Thomas Usk's Appeal, 1384 (i) 227

77 From Thomas Usk's Appeal, 1384 (ii) 228

\section{Chapter 13}

78 Chaucer's 'The Tale of Melibeus' (facsimile) 232

79 Chaucer's 'The Parson's Tale' (facsimile) 234

80 Chaucer's 'The Friar's Tale' (i) (facsimile) 236

81 Chaucer's 'The Friar's Tale' (ii) (facsimile) 237

82 End of 'The Summoner's Tale' and beginning of 'The Friar's Tale' 240 


\section{Chapter 14}

83 Letter of King Henry V, $1418 \quad$ (facsimile) 248

84 The Boke of Margery Kempe (i) 251

85 The Boke of Margery Kempe (ii) 251

86 The Boke of Margery Kempe (iii) (facsimile) 252

87 The Boke of Margery Kempe (iv) (facsimile) 253

88 Letter from Agnes to William Paston, $1440 \quad 255$

89 Letter from Margery Brews to John Paston, February $1477 \quad 256$

90 Polychronicon, John of Trevisa, $1385 \quad 258$

91 Polychronicon, Caxton's version, $1482 \quad 258$

92 Caxton on the diversity of English, 1490

93 Caxton's advertisement, 1482 (facsimile) 261

94 Caxton's The Historye of Reynart the Foxe, 1489 version (facsimile) 262

95 Sir Thomas Malory's Le Morte Darthur, c. 1460-1470 (i) (facsimile) 264

96 Sir Thomas Malory's Le Morte Darthur (ii) (facsimile) 265

97 George Cely to Richard Cely, 1478 (facsimile) 267

98 Richard Cely to Agnes, Richard and George Cely, 1479 (facsimile) 269

99 Note of events (June 1483) and memoranda by George Cely ( facsimile)

\section{Chapter 15}

100 Letter from George Bassett to Lord and Lady Lisle, 1539 ( facsimile)

101 Letter from Sir William Kingston to Lord Lisle, 1533 ( facsimile)

102 Letter from the Bishop of Carlisle to Lord Lisle, 1533 ( facsimile)

103 Proheme to The Gouernour, $1531 \quad$ (facsimile)

104 Sir Thomas Elyot's The Gouernour, 1531 (i) (facsimile) 282

105 Sir Thomas Elyot's The Gouernour, 1531 (ii) (facsimile) 284

106 Sir Thomas Elyot's The Gouernour, 1531 (iii) (facsimile) 284

107 George Puttenham on inkhorn terms, $1589 \quad$ (facsimile) 287

108 Richard Verstegan, A Restitution of Decayed Intelligence, 1605 ( facsimile)

109 John Hart's An Orthographie, $1569 \quad$ (facsimile) 289

110 John Hart's new alphabet and spelling system (facsimile) 291

111 William Bullokar's Boke at Large, $1580 \quad$ (facsimile) 299

\section{Chapter 16}

112 John Hart's An Orthographie

113 George Puttenham's Of the Arte of English Poesie, 1589 ( facsimile)

114 Shakespeare's The Life of Henry the Fift (facsimile) 309

115 Shakespeare's Much Adoe About Nothing, Scene 14 
116 Richard Verstegan (1605) on regional dialects (facsimile) 312

117 Shakespeare's The Tragedie of King Lear (facsimile) 314

\section{Chapter 17}

118 Sir Thomas Browne's Religio Medici, 1642

119 Sir Thomas Browne's Vulgar Errors 327

120 Sir Thomas Browne's Of the Badger 331

121 George Fox's Journal, 1663 (facsimile) 332

122 George Fox's handwriting (facsimile) 333

123 George Fox's Journal, 1650

124 George Fox's A Battle-Door for Teachers and Professors ( facsimile)

125 George Fox's Journal - thee and thou (i) 336

126 George Fox's Journal, 1651 - thee and thou (ii) 336

127 George Fox's Journal, 1652 (i) 336

128 George Fox's Journal, 1652 (ii) 337

129 John Milton's Areopagitica (i) (facsimile) 338

130 John Milton's Areopagitica (ii) (facsimile) 340

131 John Evelyn's Diary for 25 December 1657

132 The Publick Intelligencer, 28 December 1657

133 John Evelyn's Diary for 2 and 3 June 1658

134 Thomas Sprat's The History of the Royal Society, 1667 (facsimile) 343

135 Joshua Pool's Practical Rhetorick, 1663 (facsimile) 345

\section{Chapter 18}

136 John Bunyan's The Pilgrims Progress, Doubting Castle (facsimile) 353

137 The language of The Pilgrims Progress 354

138 Fox and Hookes' Instructions for Right Spelling, 1673 (facsimile) 356

139 Christopher Cooper's The English Teacher, 1687 (i) (facsimile) 359

140 Christopher Cooper's The English Teacher, 1687 (ii) (facsimile) 360

141 Christopher Cooper's The English Teacher, 1687 (iii) (facsimile) 361

142 Christopher Cooper's The English Teacher, 1687 (iv) (facsimile) 363

143 Christopher Cooper's The English Teacher, 1687 (v) (facsimile) 364

144 Christopher Cooper's The English Teacher, 1687 (vi) 365

145 Lines from Chaucer's Prologue 368

146 Couplets from Dryden's Aeneis, $1697 \quad 368$

147 Shakespeare's The Two Gentlemen of Verona 370

148 George Meriton's A Yorkshire Dialogue, 1683

\section{Chapter 19}

149 From The Tatler, No. 230, 26 September 1710

150 James Beattie's Theory of Language, $1774 \quad$ (facsimile) 379

151 From Jonathan Swift's A Proposal, $1712 \quad$ (facsimile) 381

152 Samuel Johnson's Plan of a Dictionary, $1747 \quad$ (facsimile) 383

153 Joseph Priestley's Rudiments of English Grammar, 1769 
154 Robert Lowth's A Short Introduction to English Grammar, 1762 (i)

( facsimile)

155 Robert Lowth's A Short Introduction to English Grammar, 1762 (ii) (facsimile)

156 Robert Lowth's A Short Introduction to English Grammar, 1762 (iii) (facsimile)

157 Robert Lowth's A Short Introduction to English Grammar, 1762 (iv) (facsimile)

158 On the language of common people

159 Samuel Johnson, from The Rambler, No. 38, July 1750

160 Edward Harwood's Liberal Translation of the New Testament (i) (facsimile)

161 St Paul's Letter to the Corinthians, chapter 13, The King James Bible, 1611

162 Edward Harwood's Liberal Translation of the New Testament (ii) ( facsimile)

163 Thomas Hearne's Remarks and Collections, 1715

164 Inventory of Elkanah Shaw's property, $1773 \quad$ (facsimile) 395

165 From a Petition to Parliament, 1793

166 From a Petition to Parliament, 1810

167 From a Petition to Parliament, 1817

398

168 From a letter to Oliver Cromwell Esquire, 27 February $1799 \quad 398$

169 William Cobbett's The Political Register, 29 November 1817

170 William Cobbett's The Life and Adventures of Peter Porcupine, 1796

171 William Cobbett's A Grammar of the English Language, 1817

400

172 William Cobbett's The Political Register, 6 December 1817 ( facsimile)

\section{Chapter 20}

173 Genesis, 3:1

St Matthew's Gospel, 26: 69-75, in eight historical versions:

174 Late West Saxon Old English, c. 1050

175 14th-century S Midlands dialect (The Wycliffite Bible)

176 Early 16th-century Scots, c. 1520

177 Early Modern English (The Rheims Bible, 1582)

178 Early Modern English (King James Bible, 1611)

179 20th-century Scots (New Testament in Scots)

180 Modern English (New English Bible, 1961)

181 Bislama (Gud Nyus Bilong Jisas Krais, 1971)

\section{Chapter 21}

182 Dean Henry Alford's The Queen's English, $1864 \quad$ (facsimile) 421

183 Contemporary spoken English

\section{Chapter 23}

184 William Tyndale's Pentateuch, $1530 \quad$ (facsimile) 